and it achieved the unique honour of being published by the underground movement; it was the main scientific book used by the students of Poland's Underground University, in which Prof. Wertenstein took an active part. Little is yet known about his fate during the war years; but he was hunted by the Germans and had to hide in various parts of the country. Finally he managed to escape to Hungary, and there, on the eve of the liberation of Budapest by the Red Army, he was killed by a shell fragment during the battle for that city.

I cannot end this note without a tribute to Prof. Wertenstein's character and personality. He possessed such virtues as made him an outstanding man even without his scientific achievements. He was exceptionally kind, generous, friendly and utterly unselfish. Everyone who knew him was charmed and attracted by his cordiality, cheerfulness and modesty. But we, his students, who worked with him closely, could most fully appreciate the integrity of his character. $\mathrm{He}$ was not merely a teacher but also a friend and counsellor; he cared not only for our intellectual needs but also for our general welfare, and would not spare any efforts to meet any of our difficulties. $\mathrm{He}$ will always remain in our memory a symbol of the ideal man of science, a perfect blend of brilliance and kindness, erudition and good humour, enthusiasm for Nature and love of humanity.

J. Rotblat.

\section{Prof. Walter Makower, O.B.E.}

THE death of Prof. W. Makower at the age of sixtyfive occurred on July 7. Makower graduated from University College, London, where he took honours in chemistry ; but going to Cambridge as a research student under Thomson effected his transformation into a physicist, and his M.A. was for a thesis on the diffusion properties of radium emanation (radon). From the Cavendish Laboratory he went to Manchester as a John Harling Research Fellow under the directorship of Schuster. On the latter's retirement in 1906, Makower became lecturer on the staff of Rutherford, whose arrival in Manchester gave a great impetus to radioactive studies. Over a period of years Makower did experimental work in this subject; he showed that radium $A, B$ and $C$ all had different temperatures of volatilization and that the behaviour of the active deposit depended largely on the pressure conditions within the vessel. Later on he collaborated with Prof. S. Russ on radioactive recoil, with Fajans on the beta-rays from radium $B$ and with Moseley on the gamma radiation from the same substance; with Geiger he wrote a timely book on radioactive measurements. He had previously written one of the earliest books on radioactivity entitled "The Radioactive Substances".

Outside the precincts of the Physics Department, Makower spent a good deal of his leisure at the kiteflying station installed high up on the moors above Glossop in Derbyshire. He escaped injury when the kite he was flying was struck, setting on fire the hut in which the winding machinery was installed.

The War of 1914-18 found him serving first as a lieutenant R.N.V.R. and then as a captain R.F.C.; both positions he filled in a scientific capaoity.

After sixteen years service in the Physics Department at Manchester, Makower became attached to the research laboratory of the Dunlop Rubber Company, but he was glad to return to professional life when appointed in 1925 to the post of professor of science at the Royal Military Academy, Woolwich. This post he held until 1938 when he resigned; he was awarded the O.B.E. in 1934.

During the years of retirement he did valuable work for the Institute of Physics.

Walter Makower came of a cultured family, all the members being musical; he was no mean performer on the 'cello. Those who knew him intimately valued him most for his sense of humour and his integrity of mind. He married Dorothy Lois Drey who, with their two daughters and a son, survives him.

\section{Miss E. R. Saunders}

ThE obituaries of Miss E. R. Saunders in Nature of August 18, 1945, while describing her morphological and educational work, do not refer to her contributions to genetics. These were, however, of the first importance. In 1897 she began experimental plant breeding at Cambridge in collaboration with Bateson, and the results were presented to the Evolution Committee of the Royal Society in 1901. Meanwhile Mendel's work had been rediscovered in 1900. By 1901 she had established the existence of Mendelian inheritance in Lychnis, Datura and Matthiola. It is clear that she and Bateson had independently rediscovered some at least of Mendel's laws before his work was known to them. She must in fact be regarded as the 'mother' of British plant genetics.

Her later genetical research was mainly on Matthiola incana. Here she successfully analysed what was then the most complicated known case of genic interaction. Any of four independent recessive genes may render a plant of this normally hoary species glabrous. Two of them also make it white. She also described, in connexion with doubleness, what, in modern terminology, is the first case of balanced lethals, and the second case of linkage. Up to her death she continued to display a lively interest in all branches of genetics, and was treasurer of the Genetical Society. To all geneticists her death was a loss ; to many a personal loss. J. B. S. HaLdaNE.

\section{Dr. G. V. Buchanan}

Dr. Gwynneth Vaughan Buchanan, senior lecturer in zoology at the University of Melbourne, died towards the end of June 1945. Dr. Buchanan was born in Sydney in November 1886, and was educated at Toorak College and the University of Melbourne. For a time she acted as professor of zoology in the University of Western Australia before she returned to her old university as senior lecturer under Sir Baldwin Spencer. To English zoologists she is perhaps best known for her outstanding work on the development of the marsupials, undertaken in conjunction with Dr. Elizabeth Frazer at University College, London, in 1918. In Australia, the great influence for good that she exercised on the many students to whom she was so much more than a mere university teacher will long be remembered. It was largely owing to her influence and enthusiasm that the McCoy Society for Field Investigation and Research came into being and became such an outstanding success. After some months of ill-health, bravely borne, she retired from active teaching in February of this year, but until the last she continued her enormous correspondence with old students scattered, by the War, to distant parts of the world.

\section{F. WOOD JONES.}

